\title{
Strengthening of Fibre Reinforced Concrete Elements: Synergy of the Fibres and External Sheet
}

\author{
Viktor Gribniak ${ }^{1, * \mathbb{C}}$, Pui-Lam Ng ${ }^{1,2}, * \mathbb{D}$, Vytautas Tamulenas ${ }^{1}$, Ieva Misiūnaitè ${ }^{1}$, \\ Arnoldas Norkus ${ }^{1}$ and Antanas Šapalas ${ }^{1}$ \\ 1 Vilnius Gediminas Technical University (VGTU), Sauletekio Av. 11, 10223 Vilnius, Lithuania \\ 2 Department of Civil Engineering, The University of Hong Kong, Pokfulam 999077, Hong Kong, China \\ * Correspondence: viktor.gribniak@vgtu.lt (V.G.); irdngpl@gmail.com (P.-L.N.); Tel.: +370-6-134-6759 (V.G.)
}

Received: 10 July 2019; Accepted: 15 August 2019; Published: 17 August 2019

check for updates

\begin{abstract}
In structural rehabilitation and strengthening, the structural members are often required to cope with larger design loading due to the upgrading of building services and design standard, while maintaining the member size to preserve the architectural dimensions and headroom. Moreover, durability enhancement by mitigating or eliminating the reinforcement corrosion problem is often desired. Concrete cracking is a major initiating and accelerating factor of the corrosion of steel reinforcement. The application of fibres is a prominent solution to the cracking problem. Furthermore, the fibres can increase the mechanical resistance of the strengthening systems. This study reveals the synergy effect of the combined application of steel fibres and external carbon fibre-reinforced polymer (CFRP) sheets. The investigation encompasses the use of fibre-reinforced polymer (FRP) reinforcing bars, discrete steel fibres, externally bonded and mechanically fastened FRP sheets in different combinations. It is discovered that the steel fibres can help to control concrete cracking and eventually alter the failure mode and enhance the flexural resistance. The FRP reinforcement system, together with the steel fibres, radically resolves the structural safety problem caused by corrosion of the steel bar reinforcement. Finally, the impact of the external sheet on the fire limit state performance needs to be resolved, such as by adopting fire protection rendering for the finishes layer.
\end{abstract}

Keywords: external sheet; fibre-reinforced polymer; mechanical fastening; steel fibre

\section{Introduction}

In structural rehabilitation and strengthening, the structural members are often required to cope with larger design loading due to the upgrading of building services and facilities and heightening of design standard, while maintaining the original member size to preserve the architectural dimensions and headroom. Moreover, durability enhancement by mitigating or eliminating the reinforcement corrosion problem is often desired to extend the service life to an acceptable level [1,2]. Concrete cracking is a major initiating and accelerating factor of the corrosion of steel reinforcement. When the concrete is uncracked, the steel reinforcement is protected by passivation in the alkaline environment within the hardened concrete, and the corrosion problem is minimal. Once the concrete is cracked, the cracks provide channels for ingress of moisture and deleterious chemicals that eventually depassivate the steel and accelerate corrosion [3,4].

Cracking is a complex physical process that begins with the proliferation of micro-cracks, which are intrinsic to the concrete. Initiated at the microstructural level, a crack becomes apparent from structural engineering viewpoint only at the mesoscale consideration. In this regard, the application of fibres is considered as an efficient solution of the cracking problems [5,6]. Fibres might also improve structural resistance in complex loading situations $[7,8]$ and impart additional ductility and deformability to the structural member $[9,10]$. In a cracked section of a member, fibres can carry a certain portion of the 
tensile stresses through the bond between fibres and surrounding concrete. Recent studies [11-13] confirmed that the presence of steel fibres helps to reduce both the crack widths and crack spacing, and improving the serviceability performance of structural members.

Furthermore, as demonstrated by previous experimental investigations [14-16], the addition of steel fibres could improve the energy dissipation of cracked concrete and effectively suppress the tendency of crushing, spalling, and shear failure of concrete. Steel fibre-reinforced concrete has been applied in multiple infrastructure projects such as vehicular and metro tunnel linings for improved resilience [17-19]. The fibres, moreover, can increase the damage resistance of the strengthening systems [20,21]. In practice, partial reconstruction can be done, by underpinning and replacing part of the existing concrete with newly cast steel fibre-reinforced concrete, such process also offers the opportunity of replacing the steel reinforcing bars with fibre-reinforced polymer (FRP) bars. The employment of FRP bars, compared to conventional reinforcing steel, offers the major advantages of high strength-to-weight ratio, high tensile strength, and free from corrosion problem [22,23]. Particular, the corrosion-free property can allow reduction of concrete cover for higher structural efficiency as well as can enhance the durability. After concrete casting and curing, the external sheet can be installed to strengthen the member. Previous research has proven the effectiveness of externally-bonded sheets in structural retrofitting and strengthening $[24,25]$. The external sheet can be bonded to the concrete surface by constructional adhesive, or additionally fastened mechanically to result in a more effective hybrid jointing [26,27]. As an illustration, Figure 1 demonstrates the efficiency of steel fibres in preventing the formation of splitting cracks in concrete prisms bonded with external carbon fibre-reinforced polymer (CFRP) sheets [28].

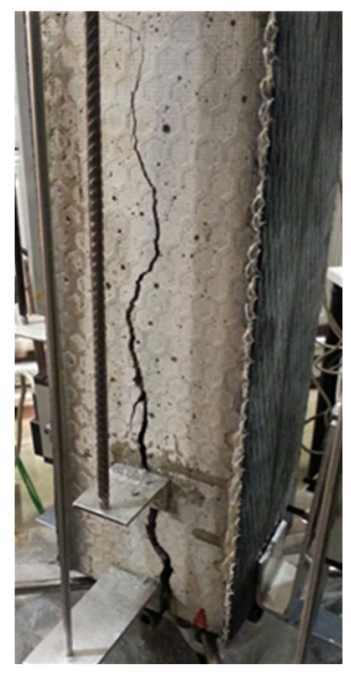

(a)

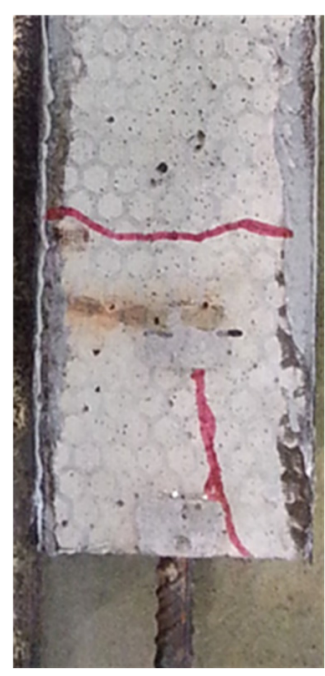

(b)

Figure 1. Failure manner of tensile concrete prisms with externally bonded carbon fibre-reinforced polymer (CFRP) sheets: (a) Splitting failure of the ordinary concrete specimen; (b) The absence of the splitting failure signs in the prism made from steel fibre-reinforced concrete.

This study reveals the synergy effect of the combined application of steel fibres and external CFRP sheets. The investigation encompasses the use of FRP reinforcing bars, discrete steel fibres, externally bonded and mechanically fastened FRP sheets in different combinations. Through the experimental study of steel fibre-reinforced concrete specimen combined with other strengthening means, similarities can be drawn on the behaviour of partially reconstructed members in practical strengthening. The FRP reinforcement system, in conjunction with the steel fibres, can radically resolve the structural safety problem related to the corrosion of steel reinforcing bars. To avert possible debonding of external sheets, a mechanical fastening system is applied so that potential sudden failure of the adhesive bond can be prevented. 


\section{Experimental Works}

The experimental programme encompasses 18 composite beam specimens. All beams had cross-sectional dimensions of $100 \mathrm{~mm}$ in breadth and $200 \mathrm{~mm}$ in height, gross length of $1500 \mathrm{~mm}$, and span length of $1240 \mathrm{~mm}$. The beams were subjected to symmetrical four-point bending with a shear span of $420 \mathrm{~mm}$ (Figure 2a). Figure 3 illustrates the reinforcement detailing of the beams. For ease of reference, the beams are assigned distinct notations. The notations with " $n m^{\prime \prime}$ refer to "non-metallic", and such beams had $2 \times \emptyset 8 \mathrm{~mm}$ GFRP (glass fibre-reinforced polymer) tension reinforcement bars and $2 \times \emptyset 6 \mathrm{~mm}$ grade $\mathrm{S} 500$ steel compression reinforcement bars. The remaining beams were reinforced with $2 \times \emptyset 8 \mathrm{~mm}$ deformed steel bars as tension reinforcement and $2 \times \emptyset 6 \mathrm{~mm}$ deformed steel bars as compression reinforcement. To prevent shear failure, $\emptyset 6 \mathrm{~mm}$ steel stirrups were provided at $50 \mathrm{~mm}$ spacing along the shear spans.

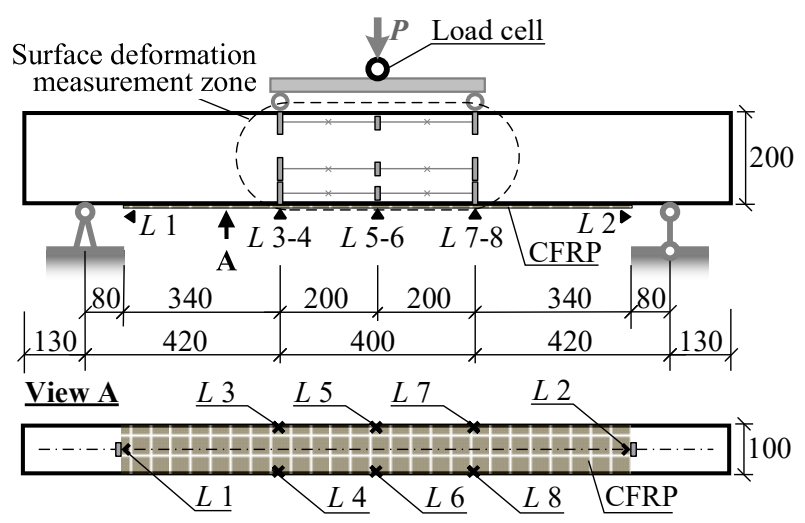

(a)

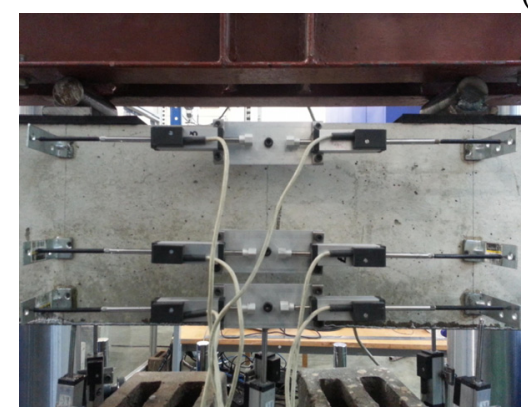

(b)

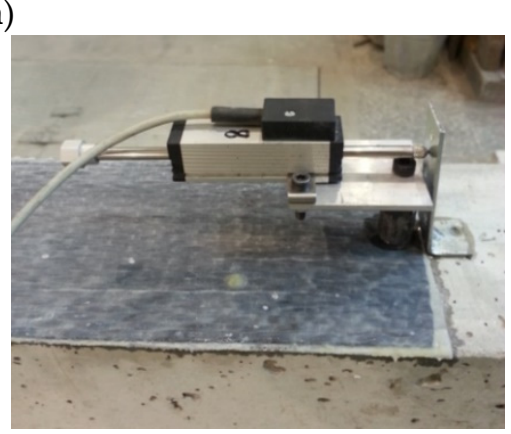

(c)

Figure 2. Test apparatus and instrumentation: (a) Loading scheme and extent of the external sheet; (b) Arrangement of linear variable displacement transducers (LVDTs) at the lateral surface of beam specimen; (c) Slip measurement of the external sheet.

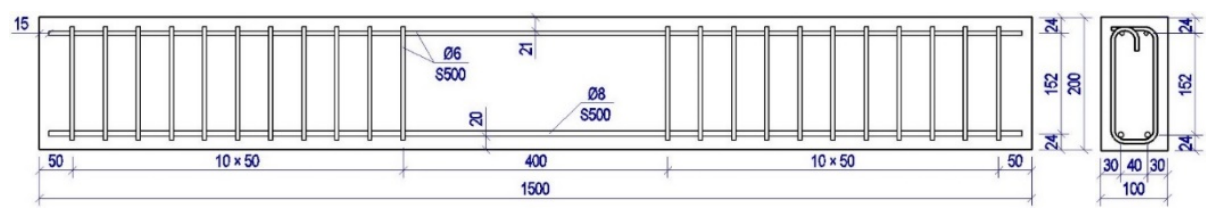

Figure 3. Reinforcement detailing of the beam specimen.

Uni-directional CFRP sheets MapeWrap C UNI-AX with mass per unit area of $300 \mathrm{~g} / \mathrm{m}^{2}$ was used for the strengthening. The equivalent thickness of the dry fabric was $0.166 \mathrm{~mm}$. As surface preparation of the substrate concrete, epoxy primer and levelling putty were applied to the concrete surface for better bonding at the concrete-to-CFRP interface. The CFRP sheets were glued to the surface using a two-component epoxy resin (MapeWrap 31). The wet lay-up system was employed for bonding multiple layers of CFRP sheets, and the detailed procedures will be explained later. 
Subsequently, the epoxy resin was cured for seven days prior to testing. Figure 2a displays the extent of the CFRP sheet at the soffit of the beam.

For each type of steel bars, three samples were tested for obtaining the average yield strength and elastic modulus, whereas the mechanical properties of FRP materials were reported by the producers. The strength and elastic modulus are expressed with respect to the nominal diameter. Yield strength of $6 \mathrm{~mm}$ and $8 \mathrm{~mm}$ diameter steel bars were $565 \mathrm{MPa}$ and $545 \mathrm{MPa}$, respectively; whereas the elastic moduli were $209 \mathrm{GPa}$ and $203 \mathrm{GPa}$ for $6 \mathrm{~mm}$ and $8 \mathrm{~mm}$ steel bars and $64.7 \mathrm{GPa}$ for $8 \mathrm{~mm}$ GFRP bar, respectively. It is noted that the elastic modulus of the GFRP bar is considerably lower than that of the steel bars and would adversely affect the stiffness of the structural element. Hence, the adoption of structural solutions, including the addition of steel fibres and installation of external sheets can help to limit the reinforcement elongation and overall deformation of the strengthened member. The tensile strength and elastic modulus of CFRP sheets were respectively $4830 \mathrm{MPa}$ and $230 \mathrm{GPa}$.

The beams were divided into three series and were produced from three concrete batches with crushed granite aggregates used in the concrete mixes. Table 1 describes the mix proportions and strength results and the major parameters of the specimens. Steel fibres with hooked ends from two suppliers were used. All steel fibre-reinforced concrete mixtures contained $0.8 \%$ steel fibres by volume. All fibres had a length of $50 \mathrm{~mm}$ and an aspect ratio of 50 . All specimens were concreted using steel mould and were demoulded in 2 or 3 days after casting. The beams were stored in laboratory conditions with an average indoor temperature of $21.1^{\circ} \mathrm{C}$ and relative humidity of $55.5 \%$.

Table 1. Mix proportions and the major parameters of the beam specimens.

\begin{tabular}{|c|c|c|c|}
\hline Series & $\mathbf{I}$ & II & III \\
\hline Notation & $\begin{array}{l}I-B 1-n m \\
I-B 2-C \\
I-B 3-C-n m\end{array}$ & $\begin{array}{c}I I-B 1-F\left(^{*}\right) \\
I I-B 2-F-C\left(^{*}\right) \\
I I-B 3-F-C-n m\end{array}$ & $\begin{array}{c}I I I-B 1-F\left(^{*}\right) \\
I I I-B 2-F-C\left(^{* *}\right) \\
I I I-B 3-F-C-A 12\left(^{*}\right) \\
\left.I I I-B 4-F-C-A 20{ }^{*}\right)\end{array}$ \\
\hline Tension reinforcement & \multicolumn{2}{|c|}{$8 \mathrm{~mm}$ steel or GFRP bars } & $8 \mathrm{~mm}$ steel bars \\
\hline Concrete mix & Mix I & Mix II & Mix III \\
\hline Age of testing, days & $1377-1431$ & $1442-1472$ & $68-88$ \\
\hline Compressive strength, $\mathrm{MPa}$ & 50.6 & 31.6 & 58.6 \\
\hline \multicolumn{4}{|c|}{ Mixture proportions, $\mathrm{kg} / \mathrm{m}^{3}$} \\
\hline Cement CEM I $42.5 \mathrm{~N}$ & $415 \pm 1 \%$ & $400 \pm 0.5 \%$ & \\
\hline Cement CEM II $52.5 \mathrm{R}$ & & & $300 \pm 0.5 \%$ \\
\hline Sand $0 / 4 \mathrm{~mm}$ & $910 \pm 2 \%$ & $905 \pm 2 \%$ & $865 \pm 1 \%$ \\
\hline Coarse aggregate $5 / 8 \mathrm{~mm}$ & $389 \pm 2 \%$ & $388 \pm 2 \%$ & $404 \pm 2 \%$ \\
\hline Coarse aggregate $8 / 11 \mathrm{~mm}$ & & & $606 \pm 2 \%$ \\
\hline Coarse aggregate $11 / 16 \mathrm{~mm}$ & $551 \pm 2 \%$ & $548 \pm 1 \%$ & \\
\hline Water & $124 \pm 5 \%$ & $174 \pm 5 \%$ & $150 \pm 3 \%$ \\
\hline $\begin{array}{c}\text { Superplasticizer } \\
\text { Steel fibre }\end{array}$ & $\begin{array}{l}\text { Stachement } 2067 \\
3.3 \pm 2 \%\end{array}$ & $\begin{array}{c}\text { MuraPlast FK } 63.30 \\
2.0 \pm 2 \% \\
\text { Mechel Nemunas } \\
60 \pm 5 \%\end{array}$ & $\begin{array}{c}\text { MC-PowerFlow } 3100 \\
4.0 \pm 1 \% \\
\text { Krampe Harex } \\
65 \pm 1 \%\end{array}$ \\
\hline
\end{tabular}

$\left.{ }^{*}\right)$ Two identical specimens were produced; $(* *)$ Four identical specimens were produced.

In Table 1, the first notation symbol ("I", "II", and "III") denotes the beam series. Beams belong to the same series were all produced at the same time. Each beam was assigned a serial number in the form of "B1", "B2", "B3" or "B4". Replicated identical specimens were produced to estimate the reliability of the test outcomes, as remarked in Table 1 . The capital letter " $C$ " in the notation describes 
the provision of external CFRP sheet at the bottom surface of the beam, whereas the letter " $F$ " denotes that the beam was produced from steel fibre-reinforced concrete. The CFRP sheets were bonded to the beam soffit by epoxy adhesive. In some specimens, the CFRP sheets were additionally fastened mechanically using steel pins. Two alternative layouts of the pins were used: $2 \times 6$ pins (annotated by "A12") and $2 \times 10$ pins (annotated by "A20"). Lastly, the notation " $n m^{\prime \prime}$ (indicating "non-metallic") determines the beam with GFRP reinforcement in the tensions zone.

The pins, used for fastening of the CFRP sheets, had a length of $25 \mathrm{~mm}$ and a diameter of $2.5 \mathrm{~mm}$ and were fabricated from grade At 800 high-strength steel. The ultimate tensile strength of steel pins by averaging the test results of three samples was $1611 \mathrm{MPa}$. Figure 4 depicts the distribution of the pins in the boundary zones of CFRP sheets. The $2 \times 6$ pins scheme refers to two groups, each of 6 pins (Figure $4 \mathrm{~b}$ ). For each group, there were two symmetric lines of pins along the longitudinal direction separated $30 \mathrm{~mm}$ apart. Along each line, there were three pins at $100 \mathrm{~mm}$ spacing. The $2 \times 10$ pins scheme refers to two groups, each of 10 pins (Figure 4c). For each group, there were two symmetric clusters of pins. Each cluster was made up of 5 pins, 3 of which were along a straight line in the same manner as those in Figure $4 \mathrm{~b}$, the remaining two pins were located close to the pin near to the beam end (this pin is used for measuring the offset distances). One of them was offset $30 \mathrm{~mm}$ towards to mid-span and $10 \mathrm{~mm}$ towards the beam side, and the other was collinear in the transverse direction and offset $20 \mathrm{~mm}$ towards the beam side. The wet lay-up of CFRP sheets followed a specific process denoted as $\left[0^{\circ} / \pm 45^{\circ} / 0^{\circ}\right]_{\mathrm{S}}$ lay-up, i.e. the middle two layers of CFRP sheet was oriented at $+45^{\circ}$ and $-45^{\circ}$ from the top and bottom layers. Such lay-up configuration in the boundary zones could avoid local failure of the external sheets [20]. More detailed descriptions of the fastening procedures were contained elsewhere [29].

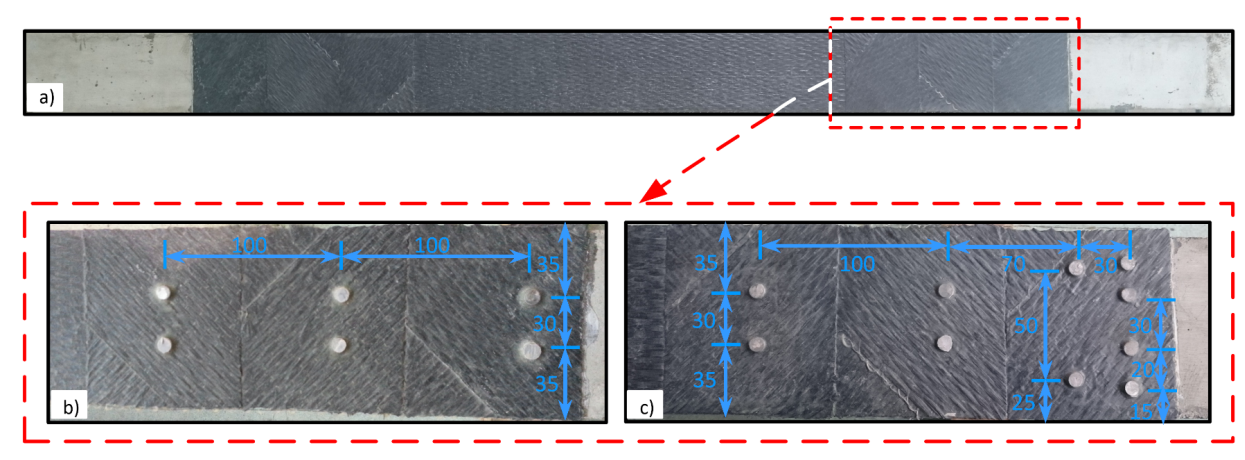

Figure 4. Mechanical fastening of external CFRP sheets (dimensions in $\mathrm{mm}$ ): (a) Adhesively bonded CFRP sheet; (b) The $2 \times 6$ pins layout; (c) The $2 \times 10$ pins layout.

Vertical displacements of the beams were measured in the pure bending zone using linear variable displacement transducers (LVDTs) ( $L 3$ to $L 8$ in Figure 2a). Three horizontal LVDT lines situated along distinct heights, as shown in Figure $2 b$ were deployed for assessing the average curvature in the pure bending zone. The upper and lower LVDT lines were located respectively along with the levels of compression and tension reinforcement, whereas the middle LVDT line was set $50 \mathrm{~mm}$ higher than the tension reinforcement level. Slip displacement of the external sheets relative to the concrete surface was measured using LVDTs ( $L 1$ and $L 2$ in Figure 2a). Figure $2 c$ shows the instrumentation. The applied load was measured using a load cell. All measured data were automatically collected and recorded by Almemo 2890-9 data-logger. The specimens were mounted in a stiff testing frame, as shown in Figure 5a and loaded using a $5000 \mathrm{kN}$ Walter + Bai hydraulic actuator with a loading rate of $0.2 \mathrm{~mm} / \mathrm{min}$. During testing, the development of cracks was monitored using a digital camera (Figure 5b), and the images were processed using digital image correlation (DIC) system with the aid of proprietary DaVis 8.1.6 software by LaVision. 


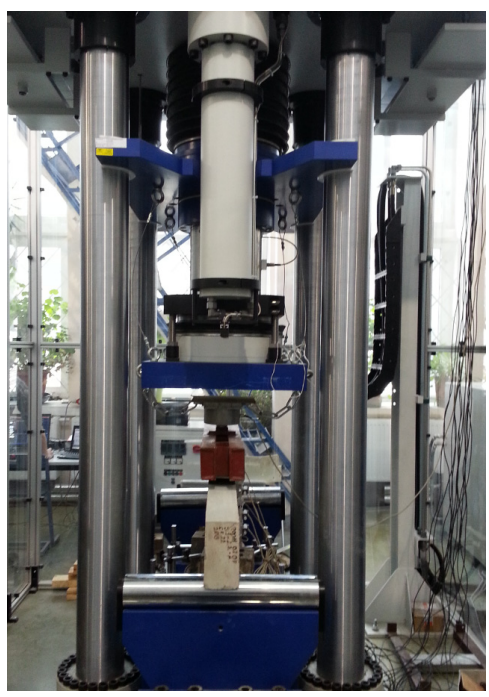

(a)

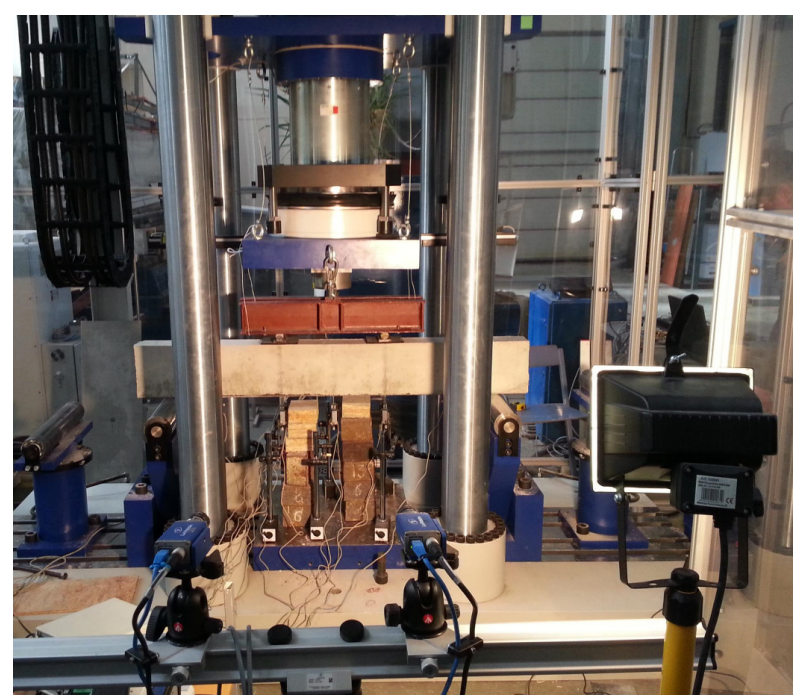

(b)

Figure 5. Test apparatus and monitoring devices: (a) Testing frame; (b) Beam specimen exposed to the digital image correlation (DIC) system.

\section{Results and Discussions}

The structural response and failure mechanisms of the externally strengthened flexural specimens are inspected. This provides a basis for investigating the synergy effects of steel fibres and the external CFRP sheets. The deformation behaviour of the specimens is considered only as a means to enable understanding of the delamination mechanisms of the external strengthening system.

\subsection{Failure Mechanisms}

Figure 6 depicts the final crack patterns of the beams belonging to the first two specimen series. This figure also describes the failure mechanism of the beams. In the figure, the specimens are divided into two groups with respect to the type of internal bar reinforcement. Identical specimens have the same notations (see Table 1 for the reference). It is found that beam specimens cast from steel fibre-reinforced concrete with external sheets exhibited larger number of cracks. This would be due to the combined effects of fibres and CFRP sheets in transferring tension stresses across a major crack, thereby increasing the stiffness and fracture energy dissipation. This synergy effect is even more apparent in conjunction with the GFRP bar reinforcement. As visualised from Figure 6, the rip-off of concrete was a typical failure mode for the specimen cast from ordinary concrete $(I-B 3-C-n m)$; whereas in the presence of steel fibres, the fibre reinforcement played the role to transfer the failure from the concrete to the interface zone, thus resulting in peeling-off the CFRP sheet (II-B3-F-C-nm). This improves the repairability of the beam, and it was achieved notwithstanding substantial differences in the compressive strength of ordinary concrete and steel fibre-reinforced concrete (the values were respectively, 50.6 and $31.6 \mathrm{MPa}$ ). The observed failure mechanisms indicate that the incorporation of fibres is more promising than increasing the concrete strength in ensuring the structural integrity of the specimens.

Splitting failure of the concrete cover at the level of tension reinforcement was a notable characteristic of the specimens without steel fibres. Figure 7a demonstrates an example of such an occurrence. For specimens cast from steel fibre-reinforced concrete with a bonded external sheet, the failure was signified by debonding of the CFRP sheets at the concrete-adhesive interface. Figure $7 \mathrm{~b}$ shows the corresponding failure example. 


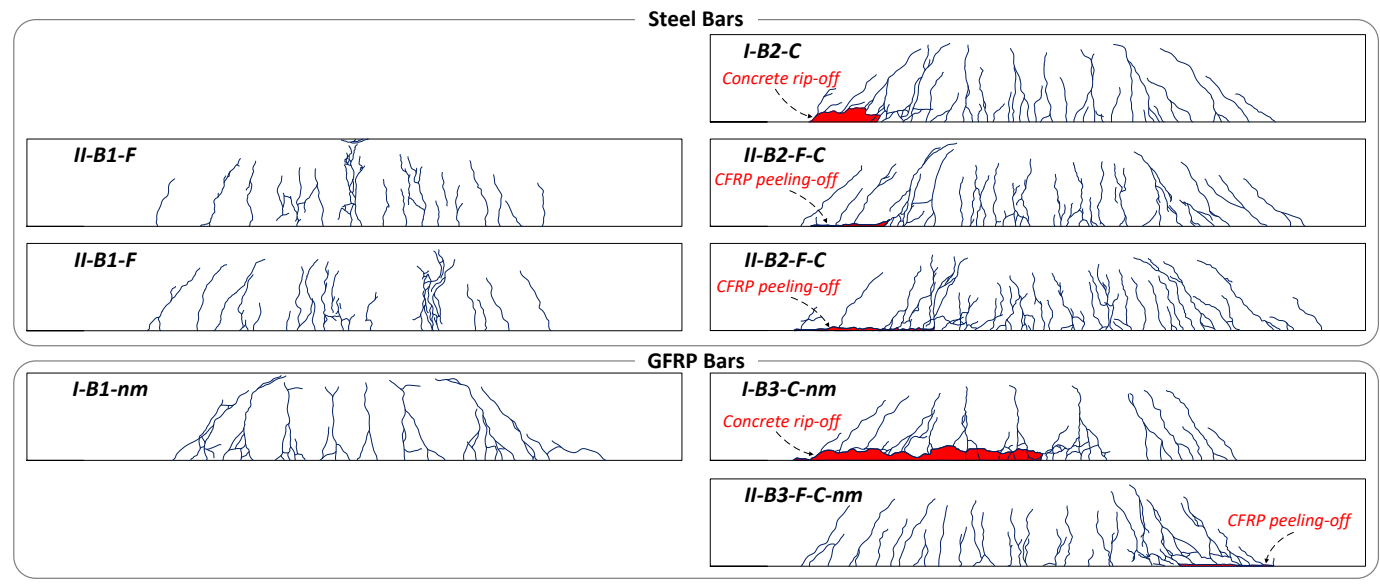

Figure 6. The final crack pattern of series " $I$ " and " $I I$ " beams.

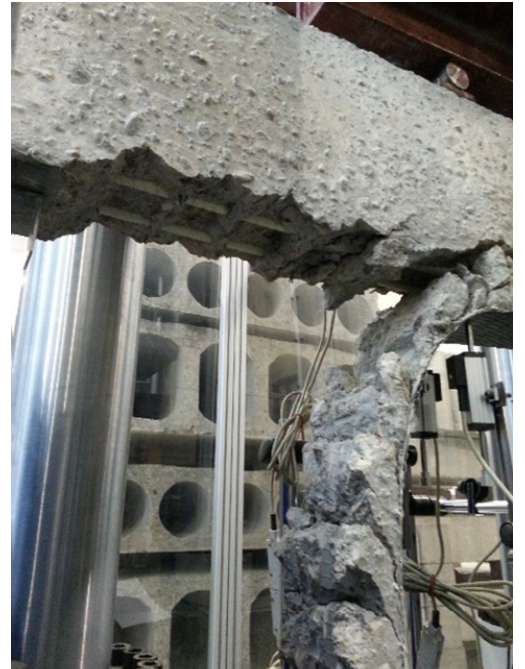

(a)

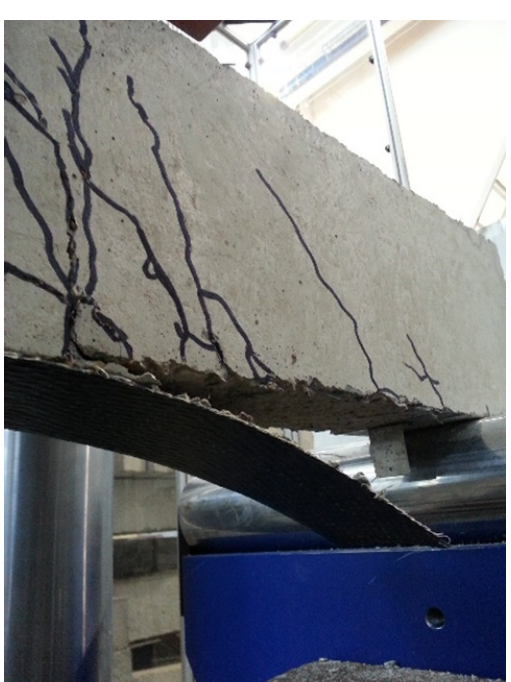

(b)

Figure 7. Failure of beam specimens: (a) The ordinary concrete beam I-B3-C-nm; (b) Beam II-B3-F-C-nm containing steel fibres.

Figure 7 shows the examples of the efficient application of steel fibres. Comparison between Figure $7 \mathrm{a}, \mathrm{b}$ reveals the effective role of steel fibres in avoiding splitting failure of concrete at the level of tension reinforcement, thus improving the ductility performance. However, the failure of the strengthened beam remained brittle due to the debonding of the external sheet. An additional mechanical fastening to the adhesive joint is useful to solve this problem. In this study, thin steel pins are used to fasten the CFRP sheets. The authors of [30,31] developed this hybrid jointing technology. Basically, on top of the epoxy adhesive, the CFRP sheet is mechanically fixed to the concrete by small steel pins. The preliminary numerical analysis using 3D finite element programme [28] demonstrated that the layout of steel pins needs to be properly designed, to avoid stress concentration problem that could risk premature failure. In-depth analysis and investigation taking into account the shearing and bearing resistances of steel pin against concrete, dowel stiffness of steel pin, foundation modulus of concrete, and the group effect of steel pins are recommended.

Figure 8 depicts the final crack pattern of the series "III" beams (Table 1). The identical specimens have the same notation. Similar to the previous two specimen series (Figure 6), the multiple cracks distributed throughout the bonded zone indicated the desirable synergy effect of the composite specimens: the smeared crack pattern along the tension zone is characteristic of the externally bonded beams, and it is noteworthy that the major cracks only formed at relatively high load levels where the load was approaching the yielding of reinforcing steel. As visualised from Figure $8 \mathrm{~b}$, the peeling-off of 
CFRP sheet was typical failure mode for the specimens with pure adhesive bonding of external sheets, whilst the additional mechanical fastening (hybrid jointing) assured adequate fixing of the external sheet up to ultimate loading stage (Figure 8c,d). The external sheet also enhanced the load-carrying capacity of the beam specimens, as demonstrated by the test results of bending moment at failure (Table 2) and discussed later.

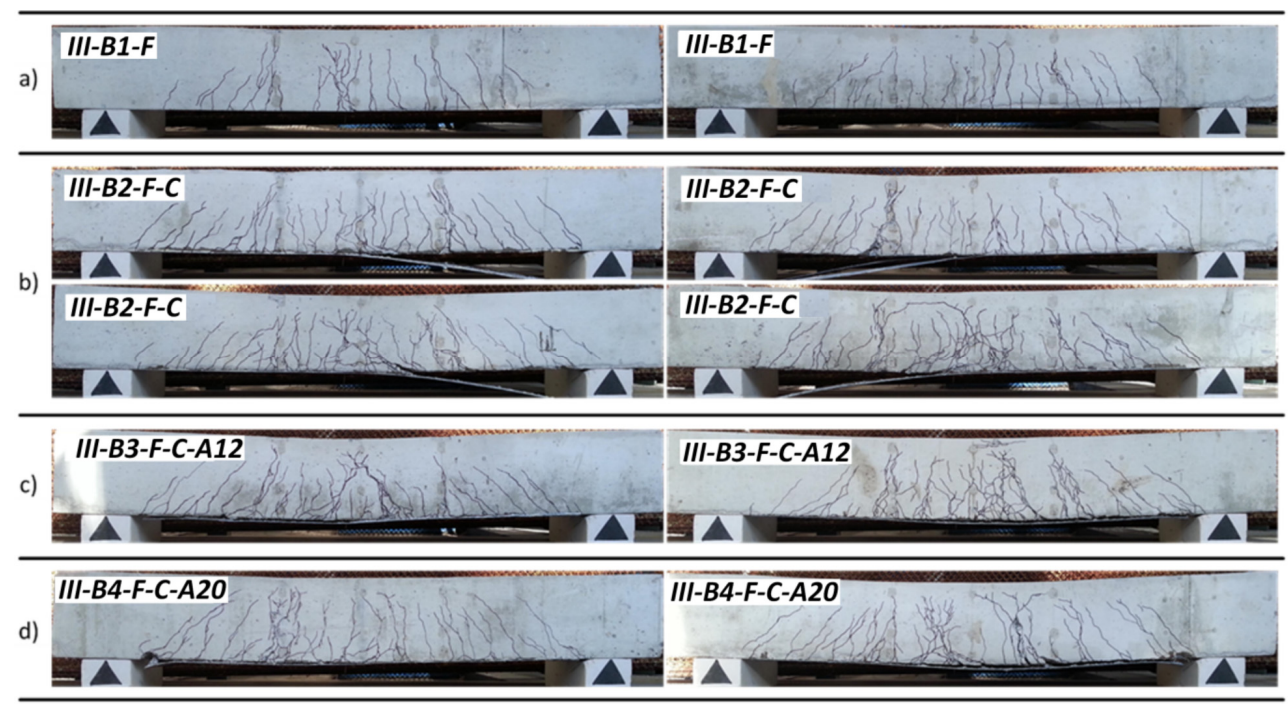

Figure 8. The final crack pattern of series "III" beams: (a) Beams without external sheet; (b) Beams with adhesively bonded sheets; (c) Beams with the additional $2 \times 6$ pins fastening; (d) Beams with the additional $2 \times 10$ pins fastening.

Table 2. Experimental results of slip of the external CFRP sheets.

\begin{tabular}{|c|c|c|c|c|}
\hline Beam & Layout of Pins & $\begin{array}{l}\text { Slip Initiation } \\
\text { Moment (kNm) }\end{array}$ & $\begin{array}{l}\text { Failure Moment } \\
(\mathbf{k N m})\end{array}$ & $\begin{array}{l}\text { Maximum } \\
\text { Slip (mm) }\end{array}$ \\
\hline \multirow{2}{*}{ III-B1-F } & & & 14.40 & \\
\hline & & & 13.83 & \\
\hline \multirow{4}{*}{$I I I-B 2-F-C$} & & 8.79 & 22.71 & 0.43 \\
\hline & & 8.01 & 21.87 & 0.23 \\
\hline & & 3.62 & 19.69 & 1.00 \\
\hline & & & 25.72 & \\
\hline \multirow{2}{*}{ III-B3-F-C-A12 } & $2 \times 6$ & 11.44 & 22.46 & 0.36 \\
\hline & $2 \times 6$ & 13.09 & 25.61 & 2.32 \\
\hline \multirow{2}{*}{ III-B4-F-C-A20 } & $2 \times 10$ & 16.06 & 24.60 & 1.50 \\
\hline & $2 \times 10$ & 10.70 & 24.46 & 1.03 \\
\hline
\end{tabular}

Figure 9 illustrates the role of mechanical fastening on the failure of external reinforcement system. In accord with the previous research findings [20], the specimens with pure adhesive bonding of CFRP sheets failed in a brittle manner upon sudden debonding of the external reinforcement (Figure 9a). Due to the different stiffness and strength of the adhesive, signs of local delamination were observed within the damaged bond area after testing, as exemplified by the beam III-B2-F-C. The two tested layouts of steel pin led to distinct outcomes. For $2 \times 6$ pins layout, part of the steel pins failed in shear as shown in Figure 9b. In contrast, for $2 \times 10$ pins layout, local failure of the concrete occurred as depicted in Figure 9c. Comparatively, failure of the fastening system was more ductile, because the steel pins were not equally stressed, during the failing process of the highly stressed pins, the remaining pins could continue to resist the slippage of the external sheet. 


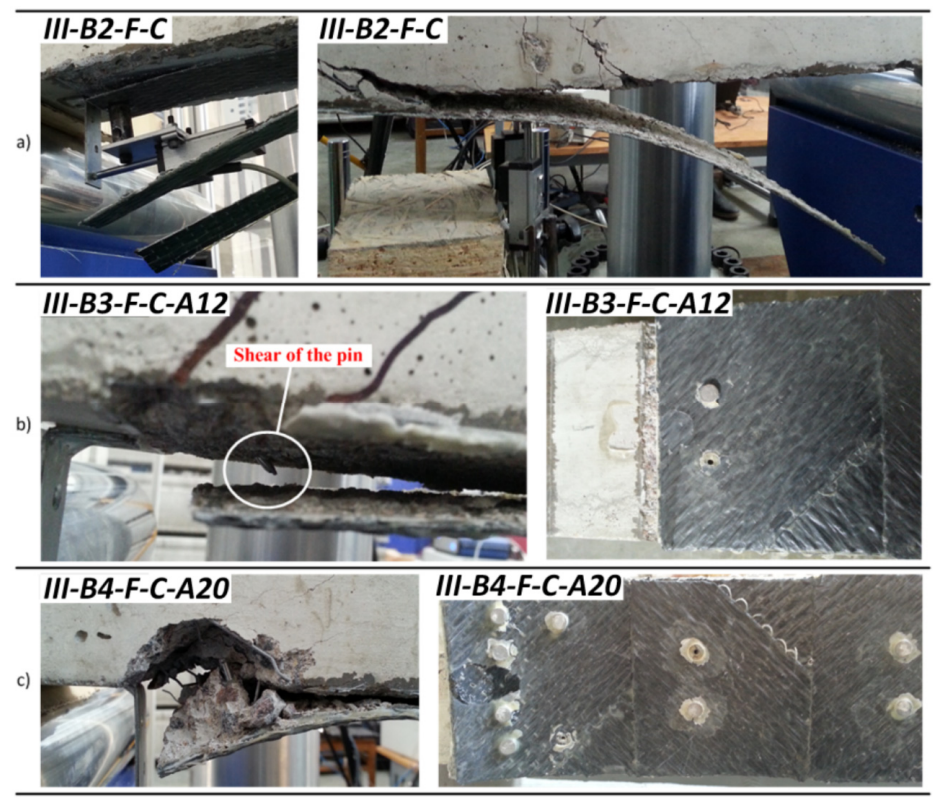

Figure 9. Failure of series "III" beams: (a) Beam with adhesively bonded CFRP sheet; (b) Beam with additional $2 \times 6$ pins fastening; (c) Beam with additional $2 \times 10$ pins fastening.

Table 2 summarises the test results of the slip of CFRP sheets from the readings of LVDTs $L 1$ and $L$ 2 (Figure $2 \mathrm{a}, \mathrm{c}$ ). It is seen that the three beams with pure adhesive bonding (III-B2-F-C) exhibited smaller bending moments at the initiation of slip. It is noted that due to the breakage of LVDT connection, the test result of one of these specimens was lost. From Table 2, the beams with hybrid jointing of CFRP sheets (III-B3-F-C-A12 and III-B4-F-C-A20) exhibited larger maximum slips. Among the beams bonded with external sheets, there was an increase in the flexural capacity ranging from $42.4 \%$ to $86.0 \%$ compared to the reference beam without external sheet (III-B1-F).

\subsection{Cracking and Deformation Behaviour}

Figures 6 and 8 show the final crack patterns of the tested beams. It is evident that the external CFRP sheet, either fixed by pure adhesive bonding or by additional mechanical fastening (hybrid jointing), was effective in distributing a small number of large cracks (as manifested in the reference beam) to a larger number of finer cracks with less crack spacing. Figure 10 demonstrates the cracking tendencies identified in the pure bending zone using the DIC system (Figure 4b). It can be seen from the figure that, at the same deflection level, the crack widths of beams with CFRP sheets were smaller than those of the reference beams. Similar results were observed in a separate study for beams bonded with external basalt FRP sheets [32]. This indicates the desirable efficiency of external sheet reinforcement in improving the serviceability performance of composite beams.

The moment-curvature response of tested beams without CFRP sheets, with CFRP sheets fixed by pure adhesive bonding, and with CFRP sheets fixed by additional mechanical fastening is compared in the following. It shows that the hybrid jointing technique by additional mechanical fastening resulted in enhanced deformation capacity and stable load-carrying capacity. Figure 11a plots moment-curvature diagrams of four beam specimens in series III without and with external sheets fixed by pure adhesive bonding, and Figure 11b plots moment-curvature diagrams of four beam specimens with the external sheets fixed by hybrid jointing technique. It can be visualised from Figure 11a that the external sheet could significantly enhance the loading capacity, until the failure of specimen which is demonstrated by beams III-B2-F-C (exhibiting debonding of CFRP sheets). From Figure 11b, during the loading process, the flexural stiffness of these specimens was rather similar, though their ultimate deformations were fairly different. At the ultimate deformation level, the respective failure characters of beams III-B3-F-C-A12 (exhibiting partial shearing of steel pins) and III-B4-F-C-A20 (exhibiting local failure of 
concrete) are not the same, as discussed in the preceding. Further research is recommended on the optimisation of mechanical fastening configuration to develop hybrid jointing technique with better structural efficiency. Moreover, where the fire resistant design is applicable, additional fire protection rendering or other means to protect the external sheet and adhesive from elevated temperature shall be duly considered. This should form part of the integrated design of the hybrid jointing in satisfying the serviceability, ultimate, and fire limit states by the structural member.

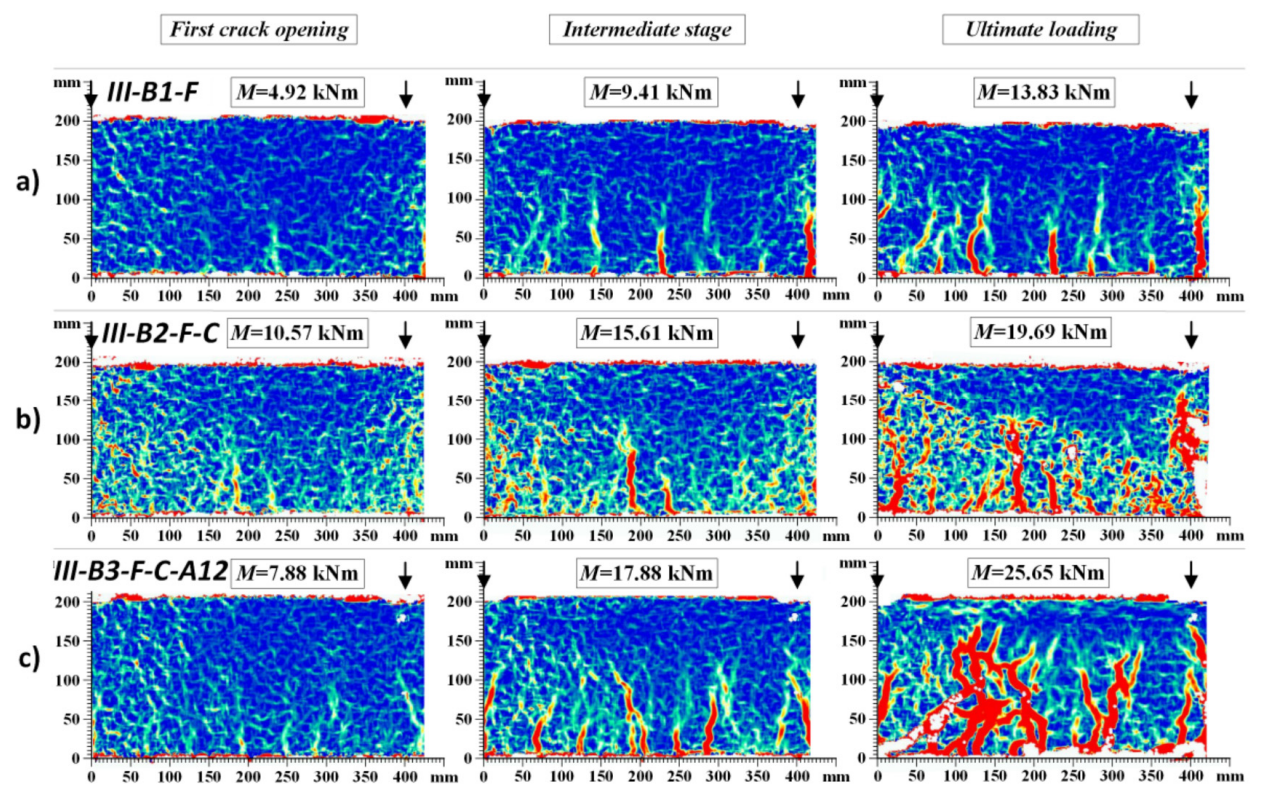

Figure 10. Development of cracks in series "III" beams identified using the DIC system: (a) Beam without external sheet; (b) Beam with adhesively bonded CFRP sheet; (c) Beam with the additional $2 \times 6$ pins fastening.

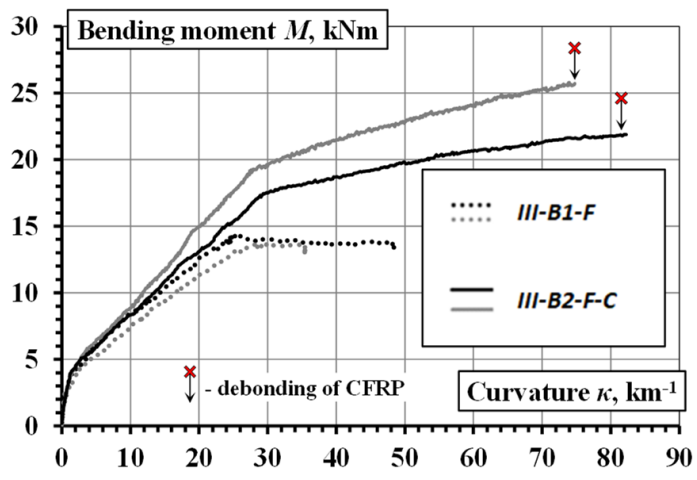

(a)

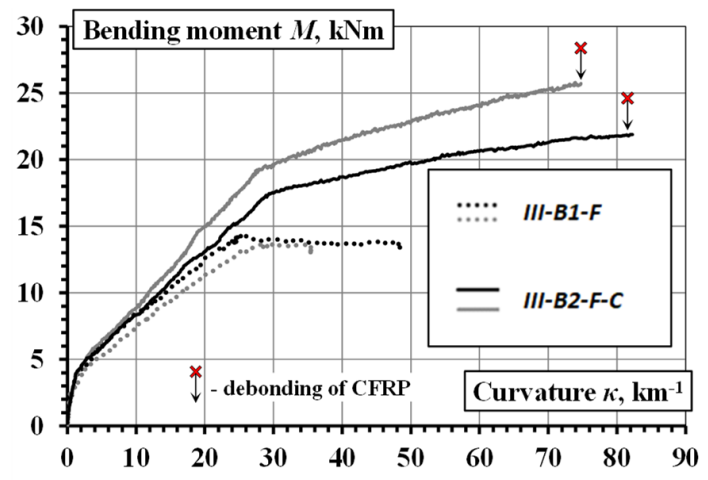

(b)

Figure 11. Moment-curvature diagrams of series "III" beams: (a) Beams without and with adhesively bonded CFRP sheets; (b) Beams with mechanically fastened CFRP sheets.

\section{Concluding Remarks}

The carbon fibre-reinforced polymer (CFRP) external sheets are a highly effective material for achieving synergy effect with the steel-fibre reinforced concrete to yield superior performance of the composite structural member. The CFRP sheets as external reinforcement could effectively suppress the localisation of major discrete cracks by transferring tensile stresses across the crack planes. The final crack patterns were represented by multiple cracks with finer crack widths distributed over the tension zone. The application of steel fibres as distributed reinforcement could alter the failure character and hence increase the flexural capacity of composite beams bonded (strengthened) with external 
CFRP sheets. While the ordinary concrete beams showed a tendency of failure by splitting of concrete cover at the level of tension reinforcement, the steel fibre-reinforced concrete beams tended to fail by debonding of external reinforcement at the concrete-adhesive interface. Through altering the failure character, the addition of steel fibres increased the flexural capacity by approximately $25 \%$ (although the failure remained in a brittle manner). Moreover, the CFRP sheets could effectively increase the energy dissipation capability and reduced the crack spacing and crack widths of composite beam specimens up to ultimate failure. The additional mechanical fastening of the CFRP sheets could increase the ultimate deformations by approximately $20 \%$ on average. Furthermore, the failure process became more gradual (improved ductility of the composite beams) and visually apparent (more prominent alert signals of distress).

From the research results, the combined use of steel fibres and external CFRP sheets with mechanical fastening to form hybrid jointing resulted in structurally efficient and robust reinforcement system. Further research is recommended on the optimisation of the fastening pins configuration and provision of fire protection to the external sheet and adhesive. The research results in this study provide useful reference to the structural rehabilitation and strengthening, where partial reconstruction can be performed to replace the existing steel reinforcing bars with FRP bars as well as to replace the existing concrete with steel fibre-reinforced concrete, followed by installation of external CFRP sheet to capture the synergy effect of steel fibre and external sheet and to achieve enhanced durability and structural performance.

Author Contributions: V.G. and A.N. proposed the idea of the works. V.G. planned the experimental works and was responsible for analysing the results. I.M. received funds for the research. V.T. performed the mechanical tests, together with P.-L.N. and A.Š., they explained the test results. V.G., P.-L.N. and I.M. wrote and revised the paper.

Funding: This research was funded by the European Social Fund (Project No. 09.3.3-LMT-K-712), the Hong Kong Special Administrative Region Research Grants Council (Project No. T22-502/18-R) and the European Commission under the Marie Skłodowska-Curie Actions (Project No. 751461). The APC was funded by the European Social Fund (Project No. 09.3.3-LMT-K-712).

Acknowledgments: Ieva Misiūnaite wishes to express her sincere gratitude to the European Social Fund funded this research within the framework of the project "Development of Competences of Scientists, other Researchers and Students through Practical Research Activities" (Project No. 09.3.3-LMT-K-712). Pui-Lam Ng wishes to acknowledge the support provided by the Hong Kong Special Administrative Region Research Grants Council under the Theme-based Research Scheme (Project No. T22-502/18-R) and the European Commission under the Marie Skłodowska-Curie Actions (Project No. 751461).

Conflicts of Interest: The authors declare no conflict of interest.

\section{References}

1. Hsu, W.L.; Liu, C.C.; Shiau, Y.C.; Lin, W.C. Discussion on the Reinforcement of Reinforced Concrete Slab Structures. Sustainability 2019, 11, 1756. [CrossRef]

2. Groli, G.; Caldentey, A.P. Improving cracking behaviour with recycled steel fibres targeting specific applications-analysis according to fib Model Code 2010. Struct. Concr. 2017, 18, 29-39. [CrossRef]

3. Gao, Y.; Zheng, Y.; Zhang, J.; Xu, S.; Zhou, X.; Zhang, Y. Time-dependent corrosion process and non-uniform corrosion of reinforcement in RC flexural members in a tidal environment. Constr. Build. Mater. 2019, 213, 79-90. [CrossRef]

4. Tahershamsi, M.; Fernandez, I.; Lundgren, K.; Zandi, K. Investigating correlations between crack width, corrosion level and anchorage capacity. Struct. Infrastruct. Eng. 2017, 13, 1294-1307. [CrossRef]

5. Barros, J.A.O.; Cunha, V.M.C.F.; Ribeiro, A.F.; Antunes, J.A.B. Post-cracking behaviour of steel fibre reinforced concrete. Mater. Struct. 2005, 38, 47-56. [CrossRef]

6. Di Prisco, M.; Plizzari, G.; Vandewalle, L. Fibre reinforced concrete: New design perspectives. Mater. Struct. 2009, 42, 1261-1281. [CrossRef]

7. Chao, S.-H.; Pareek, T.; Sahoo, D.R. Effect of fiber reinforced concrete in members with highly complex stress fields. In High Performance Fiber Reinforced Cement Composites 6, RILEM State of the Art Reports; 
Parra-Montesinos, G.J., Reinhardt, H.W., Naaman, A.E., Eds.; RILEM Publications S.A.R.L.: Paris, France, 2012; Volume 2, pp. 213-220.

8. Chu, S.H.; Kwan, A.K.H. A new method for pull out test of reinforcing bars in plain and fibre reinforced concrete. Eng. Struct. 2018, 164, 82-91. [CrossRef]

9. Aoude, H.; Belghiti, M.; Cook, W.D.; Mitchell, D. Response of Steel Fiber-Reinforced Concrete Beams with and without Stirrups. Aci Struct. J. 2012, 109, 359-367.

10. Zhou, Y.; Xiao, Y.; Gu, A.; Lu, Z. Dispersion, workability and mechanical properties of different steel-microfiber-reinforced concretes with low fiber content. Sustainability 2018, 10, 2335. [CrossRef]

11. Deluce, J.R.; Vecchio, F.J. Cracking behavior of steel fiber-reinforced concrete members containing conventional reinforcement. Aci Struct. J. 2013, 110, 481-490.

12. Amin, A.; Foster, S.J.; Watts, M. Modelling the tension stiffening effect in SFR-RC. Mag. Concr. Res. 2016, 68, 339-352. [CrossRef]

13. Bernardi, P.; Michelini, E.; Minelli, F.; Tiberti, G. Experimental and numerical study on cracking process in RC and R/FRC ties. Mater. Struct. 2016, 49, 261-277. [CrossRef]

14. Yin, J.; Wu, Z.S. Structural performances of short steel-fiber reinforced concrete beams with externally bonded FRP sheets. Constr. Build. Mater. 2003, 17, 463-470. [CrossRef]

15. Li, L.; Guo, Y.; Liu, F. Test analysis of FRC beams strengthened with externally bonded FRP sheets. Constr. Build. Mater. 2008, 22, 315-323. [CrossRef]

16. Chalioris, C.E.; Kosmidou, P.-M.K.; Karayannis, C.G. Cyclic response of steel fiber reinforced concrete slender beams: An experimental study. Materials 2019, 12, 1398. [CrossRef]

17. De Rivaz, B. Steel fiber reinforced concrete (SFRC): The use of SFRC in precast segment for tunnel lining. Water Energy Int. 2009, 66, 75-84.

18. International Tunnelling and Underground Space Association. Twenty Years of FRC Tunnel Segments Practice: Lessons Learnt and Proposed Design Principles; ITA Report No. 16; ITA-AITES: Lausanne, Switzerland, 2016; p. 71. ISBN 978-2-970-1013-5-2.

19. ACI Committee 544. Report on Design and Construction of Fiber Reinforced Precast Concrete Tunnel Segments; ACI 544.7R-16; American Concrete Institute: Farmington Hills, MI, USA, 2016; 36p.

20. Gribniak, V.; Arnautov, A.K.; Norkus, A.; Tamulenas, V.; Gudonis, E.; Sokolov, A. Experimental investigation of the capacity of steel fibers to ensure the structural integrity of reinforced concrete specimens coated with CFRP sheets. Mech. Compos. Mater. 2016, 52, 401-410. [CrossRef]

21. Gribniak, V.; Arnautov, A.K.; Norkus, A.; Kliukas, R.; Tamulenas, V.; Gudonis, E.; Sokolov, A. Steel fibres: Effective way to prevent failure of the concrete bonded with FRP sheets. Adv. Mater. Sci. Eng. 2016, 2016, 4913536. [CrossRef]

22. Bakis, C.E.; Bank, L.C.; Brown, V.L.; Cosenza, E.; Davalos, J.F.; Lesko, J.J.; Machida, A.; Rizkalla, S.H.; Triantafillou, T.C. Fiber-reinforced polymer composites for construction-state-of-the-art review. J. Compos. Constr. Asce 2002, 6, 73-87. [CrossRef]

23. Zaman, A.; Gutub, S.A.; Wafa, M.A. A review on FRP composites applications and durability concerns in the construction sector. J. Reinf. Plast. Compos. 2013, 32, 1966-1988. [CrossRef]

24. Hollaway, L.; Teng, J.G. Strengthening and Rehabilitation of Civil Infrastructures Using Fibre-Reinforced Polymer (FRP) Composites; Woodhead Publishing: Cambridge, UK, 2008; p. 398.

25. Rasheed, R.A. Strengthening Design of Reinforced Concrete with FRP; CRC Press: Boca Raton, FL, USA, 2015; p. 230.

26. Grelle, S.V.; Sneed, L.H. Review of anchorage systems for externally bonded FRP laminates. Int. J. Concr. Struct. Mater. 2013, 7, 17-33. [CrossRef]

27. Ali, A.; Abdalla, J.; Hawileh, R.; Galal, K. CFRP mechanical anchorage for externally strengthened RC beams under flexure. Phys. Procedia 2014, 55, 10-16. [CrossRef]

28. Gribniak, V.; Arnautov, A.K.; Kaklauskas, G.; Jakstaite, R.; Tamulenas, V.; Gudonis, E. Deformation analysis of RC ties externally strengthened with FRP sheets. Mech. Compos. Mater. 2014, 50, 669-676. [CrossRef]

29. Gribniak, V.; Tamulenas, V.; Ng, P.-L.; Arnautov, A.; Gudonis, E.; Misiunaite, I. Mechanical behavior of steel fiber-reinforced concrete beams bonded with external carbon fiber sheets. Materials 2017, 10, 666. [CrossRef]

30. Arnautov, A.K.; Nasibullins, A.; Gribniak, V.; Blumbergs, I.; Hauka, M. Experimental characterization of the properties of double-lap needled and hybrid joints of carbon/epoxy composites. Materials 2015, 8, 7578-7586. [CrossRef] 
31. Arnautov, A.K.; Kulakov, V.; Andersons, J.; Gribniak, V.; Juozapaitis, A. Experimental investigation on stiffness and strength of single-lap joints in a laminated CFRP stress-ribbon strip. Balt. J. Road Bridge Eng. 2016, 11, 120-126. [CrossRef]

32. Gribniak, V.; Arnautov, A.K.; Kaklauskas, G.; Tamulenas, V.; Timinskas, E.; Sokolov, A. Investigation on application of basalt materials as reinforcement for flexural elements of concrete bridges. Balt. J. Road Bridge Eng. 2015, 10, 201-206. [CrossRef] 